Syntax Literate : Jurnal Ilmiah Indonesia p-ISSN: 2541-0849 e-ISSN : 2548-1398

Vol. 5 No. 3 Maret 2020

\title{
EFEKTIVITAS PERPUSTAKAAN KELILING DALAM MENINGKATKAN INDEKS LITERASI BACA KOTA CIREBON
}

\author{
Taufik Ridwan, Muhammad Muqoyim dan Moh. Syauqi \\ Institut Agama Islam Bunga Bangsa Cirebon (IAI BBC) \\ Email: taufikridwan98@gmail.com, zidniilma1789@gmail.com,dan \\ mohammadsyaoqisyaoqi@gmail.com
}

\begin{abstract}
Abstact
The aim and study is to improve the reading literacy index as an innovation to improve local library services to the people of the city of Cirebon. This study uses literature and field studies sourced from primary and secondary data for 20192020. The results of this study indicate that the mobile library is very important to do in the city of Cirebon, namely as an effort to improve local library services and as an effort to improve the reading literacy index of the people of Cirebon.
\end{abstract}

Keywords : Effectiveness, Mobile Library, Literacy Index

\begin{abstract}
Abstrak
Tujuan dan kajian ini adalah untuk meningkatkan indeks literasi baca sebagai inovasi peningkatan layanan perpustakaan daerah kepada masyarakat di kota Cirebon. Kajian ini menggunakan studi literatur dan lapangan yang bersumber dari data primer dan data sekunder tahun 2019-2020. Hasil dari kajian ini menunjukkan bahwa perpustakaan keliling sangat penting dilakukan di kota Cirebon yaitu sebagai upaya peningkatan layanan perpustakaan daerah dan sebagai salah satu upaya untuk meningkatkan indeks literasi baca masyarakat Kota Cirebon.
\end{abstract}

Kata kunci: Efektivitas, Perpustakaan Keliling, Indeks Literasi

\section{Pendahuluan}

Perpustakaaan berasal dari kata pustaka, yang berarti buku. Setelah mendapat awalan per- dan akhiran -an menjadi perpustakaan yang berarti kitab. Kumpulan bukubuku, yang kemudian disebut koleksi bahan pustaka. Istilah ini berlaku untuk perpustakaan yang masih bersifat tradisional atau konvensional (Zen, 2006).

Perpustakaan adalah sebuah instansi yang dibentuk dalam rangka untuk mencerdaskan dan meningkatkan pengetahun umat manusia. Maka dalam hal ini, perpustakaan adalah lembaga pengelolaan dan pelayana serta penyimpanan berbagai sumber infomasi yang diperuntukan bagi seluruh masyarakat. Dalam perkembangannya, perpustakaan mempunyai beberapa fungsi, salah satunya adalah berfungsi sebagai wadah pendidikan, penelitian, pelestarian, informasi dan rekreasi. Dalam menjalankan fungsi sebagai wadah informasi, Perpustakaan Umum Kota harus bisa 
memberikan informasi kepada masyarakat secara optimal. Agar masyarakat bisa memperoleh informasi yang dibutuhkan serta menambah pengetahuan dan informasi dalam mengembangkan kemampuan masing-masing.

Di dalam bukunya Zulfikar Zen menjelaskan bahwa: Sebuah perpustakaan harus memenuhi persyaratan tertentu, yaitu:

1. Adanya kumpulan buku-buku, dan bahan pustaka laiannya, baik yang tercetak, terekam maupun dalam bentuk lain sesuai dengan perkembangan ilmu pengetahuan dan teknologi.

2. Koleksi tersebut ditata menurut suatu sistem tertentu, diolah dan diproses meliputi registrasi, identifikasi, klasifikasi, katalogisasi dan dilengkapi dengna perlengkapan koleksi, seperti slip buku, buku-buku katalog, kantong buku dan lain sebagainya.

3. Semua sumber informasi ditempatkan di gedung atau ruangan tersendiri dan sebaiknya tidak disatukan dengan kantor atau kegiatan yang lainnya.

4. Perpustakaan dikelola oleh petugas-petugas dengan persyaratan tertentu untuk melayani dengan sebaik-baiknya.

5. Ada masyarakat pemakai perpustakaan, baik untuk membaca, meminjam, meneliti, menggali, menimba, dan mengembangkan ilmu pengetahuan sehingga perpustakaan disebut sebagai gudang ilmu

Kemajuan suatu bangsa sangat ditentukan oleh kualitas sumber daya manusianya.

Dan kualitas SDM bisa diukur melalui seberapa baik kecerdasan dan pengetahuan masyarakatnya. Menurut Poespowardojo dalam (Nurdiana, 2018) peningkatan kualitas dan kompetensi SDM adalah jalan paling baik untuk mengentaskan masalah penganggurandi samping dibukakannya lapangan pekerjaan. Sedangkan pengetahuan didapat dari seberapa banyak informasi yang diperoleh, baik berupa informasi secara lisan, cetak maupun secara digital. Salah satu wadah untuk mendapatkan informasi tersebut adalah perpustakaan. Dalam rangka untuk meningkatkan kualitas SDM, perpustakaan daerah memberikan layanan perpustakaan keliling (pusling) kepada masyarakat di kota Cirebon, khususnya untuk anak-anak SD dan anak usia dini (PAUD).

Penanaman untuk gemar membaca harus dimulai sejak dini, agar budaya membaca sudah tertanam dan menjadi aktivitas sehari-hari. Oleh karena itu, tingkat indeks literasi baca perlu ditingkatkan, agar masyarakat bisa menjadi masyarakat informasi yang berkualitas dan budaya membaca bisa membumi di Kota Cirebon. Untuk melakukan hal tersebut bukanlah hal yang mudah karena membutuhkan kerjasama yang baik dari berbagai pihak. Dalam pembentukan masyarakat informasi yang berkualitas dan generasi milineal yang suka membaca, maka dibutuhkan sebuah inovasi baru agar hal tersebut dapat berjalan pada era keterbukaan informasi publik ini. Apalagi pada daerah yang tingkat minat bacanya masih rendah dan masih banyaknya masyarakat yang aliterate dan iliterate. Salah satu contohnya pada daerah Kota Cirebon.

Kota Cirebon merupakan salah satu kota di provinsi Jawa Barat yang sampai saat ini masih meningkatkan kualitas pedidikannya. Masih rendahnya minat baca masyarakatnya, menjadi salah satu faktor penyebab kurangnya daya saing SDM kota Cirebon. Meskipun sudah banyak perguruan tinggi yang bermunculan di Kota Cirebon, 
namun hal itu belum bisa menggerakkan hati masyarakat kota Cirebon untuk berbondong-bendong membaca berbagai literasi atau mengunjungi perpustakaan sebagai salah satu upaya untuk menambah pengetahuan dan informasi yang berkualitas.

Perekonomian Kota Cirebon dipengaruhi oleh letak geografis yang strategis dan karakteristik sumber daya alam sehingga struktur perekonomiannya didominasi oleh sektor industri pengolahan, sektor perdagangan, hotel dan restoran, sector pengangkutan dan komunikasi serta sektor jasa.

Masyarakat Kota Cirebon sendiri juga masih banyak yang aliterate dan iliterate, artinya masih adanya anggapan bahwa pendidikan tidak begitu penting dan masih ditemukan anak yang putus sekolah diusia dini. Hal tersebut menyebabkan kualitas SDM menjadi rendah dan kurang memiliki daya saing. Permasalahan tersebut, membuat penulis tertarik untuk membuat penelitian terkait layanan perpustakaan keliling dalam upaya meningkatkan indeks literasi baca masyarakat dan mengurangi tingkat ke aliterate dan iliterate pada masyarakat. Layanan ini merupakan inovasi baru yang diterapkan oleh perpustakaan daerah dalam meningkatkan layanan terhadap masyarakat kota Cirebon.

Perpustakaan keliling ini juga bertujuan untuk memajukan masyarakat Kota Cirebon agar bisa lebih membuka wawasan dengan meningkatkan indeks literasi baca dan kegemaran membaca melalui PUSLING. Selain itu juga dapat membantu Pemerintah Daerah dalam meningkatkan dan mengembangkan keilmuan masyarakat (baik anak-anak, remaja maupun orang dewasa) yang ada di Kota Cirebon.

Dalam artikel ini penulis akan membahas mengenai layanan perpustakaan keliling yang dilakukan sebagai inovasi peningkatan layanan Perpustakaan daerah kepada masyarakat di Kota Cirebon. Berdasarkan uraian diatas, penelitian ini penting dilakukan untuk:

1. Memaparkan mengenai gambaran umum dari Kota Cirebon

2. Memaparkan pentingnya peningkatan layanan Perpustakaan daerah

Menjelaskan strategi dan mengimplementasikannya dalam kegiatan layanan perpustakaan keliling. Adapaun pertanyaan penelitian dalam artikel ilmiah ini ialah (1) Bagaimana gambaran umum dari Kota Cirebon? (2) Bagaimana pentingnya peningkatan layanan di Perpustakaan daerah? (3) Bagaimana strategi penerapan layanan perpustakaan keliling? (4) apa saja bentuk layanan perpustakaan keliling yang akan diimplementasikan di Kota Cirebon?

\section{Metode Penelitian}

Penelitian ini menggunakan desain deksriptif. Tujuan desain penelitian deskriptif sebagaimana dijelaskan oleh (Sekaran, 2006) adalah untuk mendeskripsikan aspek-aspek yang releven dari suatu fenomena yang dipelajari peneliti dari seorang individu, organisasi, industri, atau perspektif lain. Dengan demikian penelitian deskriptif menyajikan data dalam bentuk yang sangat bermakna sehingga membantu untuk memahami karakteristik dari suatu kelompok, membantu dalam pemikiran secara sistimatis tentang aspek-aspek dalam situasi tertentu, menyediakan ide untuk pencarian dan penelitian lebih lanjut, dan membantu dalam pengambilan keputusan. Desain 
penelitian menunjukkan proses penelitian mulai dari perencanaan sampai dengan analisis untuk memperoleh temuan penelitian (Ekasari et al., 2017)

\section{Hasil dan Pembahasan}

\section{Analisa Data}

Berdasarkan Standar Nasional Perpustakaan (SNP), Perpustakaan Umum Kabupaten/Kota adalah perpustakaan yang diperuntukkan bagi masyarakat luas di daerah Kabupaten/Kota sebagai sarana pembelajaran sepanjang hayat, tanpa membedakan usia, ras, agama, status sosial ekonomi, dan gender (Perpustakaan Nasional, 2011).

Perpustakaan umum mempunyai fungsi sebagai pusat pengetahuan dan informasi, menjadikannya sebagai wadah yang strategis untuk tempat berdiskusi, mengerjakan tugas kuliah serta sekolah, dan sebagainya (Ayuningtyas, 2015).

Pelayanan perpustakaan merupakan kunci utama dalam penyelenggaraan perpustakaan dan menjadi tanggung jawab profesional setiap tenaga kerja perpustakaan untuk selalu memiliki motivasi, wawasan yang luas dan berupaya secara aktif agar dapat melaksanakan pelayanan perpustakaan yang baik (Aulawi, 2011).

Menurut (Purboningsih, Muluk, \& Noor, 2014) peningkatan kualitas pelayanan perpustakaan umum adalah kegiatan yang harus dilaksanakan secara berkelanjutkan, yaitu untuk mempertahankan kelangsungan hidup organisasi tersebut, sehingga perpustakaan umum dapat menjalankan fungsinya sebagai wadah pendidikan, informasi, penelitian dan rekreasi. Dalam peningkatan layanan Perpustakaan Umum Kabupaten/Kota, Pemerintah Daerah mempunyai peran yang sangat penting sebagai penentu arah pengelolaan dan pengembangan perpustakaan.

Peningkatan layanan perpustakaan umum dapat dilakukan dengan berbagai cara, yaitu perbaikan manajemen, peningkatan kualitas dan peran pustakawan, pengelolaan informasi dengan benar, membentuk jaringan yang selevel, penanaman profesionalisme layanan pada SDM di perpustakaan dan promosi (Hs, 2009).

\section{Strategi Kegiatan Layanan Peprustakaan Keliling Kota Cirebon}

Adapun strategi yang akan dilakukan dalam kegiatan layanan PUSLING ini yaitu sebagai berikut:

a. Pembentukan Tim PUSLING

Tim PUSLING dibentuk. dalam rangka untuk memberikan berbagai layanan dalam PUSLING. Tim ini terdiri dari beberapa petugas Pustakawan yang ditunjuk dan memiliki beberapa keahlian dalam rangka untuk menyampaikan pesan-pesan dan informasi serta mampu untuk menarik minat masyarakat agar mau membaca.

b. Pemilahan Buku

Pemilahan buku ini merupakan suatu yang harus dilakukan agar bukubuku yang dibawa bisa memenuhi kebutuhan masyarakat dalam mencari literasi. Oleh karena itu, Pemilahan ini juga harus disesuaikan dengan tingkat pendidikan dan latar belakang masyarakat 
c. Kerjasama

Dalam kegiatan PUSLING ini akan dilakukan kerjasama dengan berbagai pihak terkait, yaitu Pemerintah Daerah terkait, para pegiat literasi dari Daerah lain, pemuda-pemudi (siswa/i dan mahasiswa/i) dan warga setempat yang membutuhkan layanan PUSLING. Kerjasama dengan berbagai pihak diatas ialah bertujuan untuk mempermudah proses kegiatan PUSLING, yang dilakukan sebagai cara dalam peningkatkan layanan Perpustakaan Daerah kepada masyarakat.

d. Dana (biaya)

Dana (biaya) yang dibutuhkan untuk kegiatan PUSLING ini ialah biaya perawatan dan pengembangan PUSLING (biaya tenaga kerja, para pegiat literasi dan pelaksanaan program kegiatan) akan disesuaikan dengan kebutuhan dan keadaan dari kegiatan PUSLING.

\section{Kegiatan Yang Akan Di Implementasikan Pada Perpustakaan Keliling}

Adapun kegiatan yang akan dilakukan dalam kegiatan PUSLING, yaitu sebagai berikut:

a. Storytelling

Menurut (Habsari, 2017) dongeng adalah suatu cerita yang mengandung nilai-nilai moral dan sosial yang berguna untuk membentuk karakter anak. Teknik mendongeng yang baik akan memberikan hasil yang luar biasa terhadap dunia pendidikan anak usia dini, karena dongeng mengandung kebenaran dan memberikan ajaran moral (Utomo, 2013).

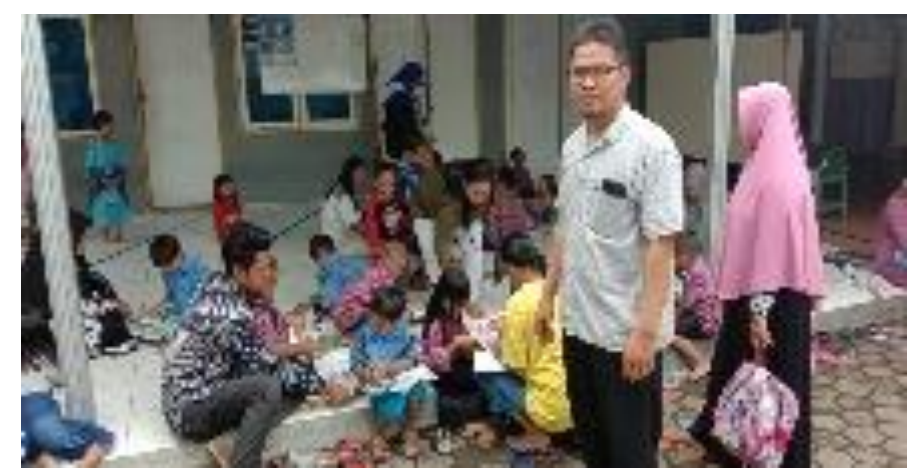

\section{Gambar 1 Storytelling}

Dari uraian diatas dapat disimpulkan bahwa mendongeng (storytelling) merupakan kegiatan yang dilakukan untuk memberikan nilainilai moral dan sosial kepada seseorang yang akan berguna dalam membentuk karakternya.

Storytelling (bercerita/mendongeng) merupakan kegiatan yang akan dilakukan oleh petugas Pustakawan untuk anak-anak (PAUD, TK/SD) dalam rangka menanamkan moral yang baik melalui cerita-cerita yang disukai oleh mereka. Storytelling ialah kegiatan yang dilakukan dengan menceritakan ulang cerita-cerita dari daerah setempat, legenda, novel dan koleksi lainnya yang bisa menarik minat dan memotivasi masyarakat di Kota Cirebon untuk 
gemar membaca dan meningkatkan kemampuan literasi mereka.

b. Bimbingan literasi

Berdasarkan Year Book of Education (1995) dalam (Tedja, 2017) bimbingan literasi adalah suatu proses untuk membantu individu melalui usahanya sendiri dalam menemukan dan mengembangkan kemampuan agar bisa memperoleh kebahagiaan pribadi dan kemanfaatan sosial. Bimbingan literasi merupakan kegiatan yang perlu dilakukan saat ini kepada setiap individu di lingkungan masyarakat. Kegiatan ini dilakukan untuk membantu individu agar bisa memiliki pemahaman dan bisa mengarahkan diri sendiri di lingkungan masyarakat.

Bimbingan literasi merupakan kegiatan bimbingan yang dilakukan dengan berbagai jenis kegiatan literasi, yaitu meliputi bimbingan literasi dasar, literasi informasi, literasi pariwisata dan sebagainya. Kegiatan bimbingan literasi ini akan dilakukan secara bertahap dan menyesuaikan dengan permasalahan yang terdapat di lingkungan masyarakat. Bimbingan literasi ini akan dilakukan oleh petugas pustakawan dan pihak terkait lainnya yang ingin ikut berpartisipasi dalam kegiatan bimbingan literasi dari kegiatan PUSLING.

c. Perpustakaan keliling

Menurut M.Ali (2006) dalam (Aji \& Heriyanto, 2013) perpustakaan keliling adalah perpustakaan yang bergerak dengan membawa bahan pustaka seperti buku, majalah, koran, dan bahan pustaka lainnya untuk melayani masyarakat dari satu tempat ke tempat lainnya yang belum terjangkau oleh layanan perpustakaan umum. Perpustakaan keliling memiliki tugas dan fungsi untuk melayani masyarakat yang belum terjangkau oleh layanan perpustakaan yang menetap seperti perpustakaan umum kota/daerah (Kadariyah, 2014). Layanan perpustakaan keliling pada dasarnya bersifat terbuka dan demokratis, karena tujuannya ialah untuk melayani semua lapisan masyarakat tanpa membedakan status sosial, budaya, ekonomi, pendidikan, kepercayaan dan status lainnya (Wibowo, 2010).

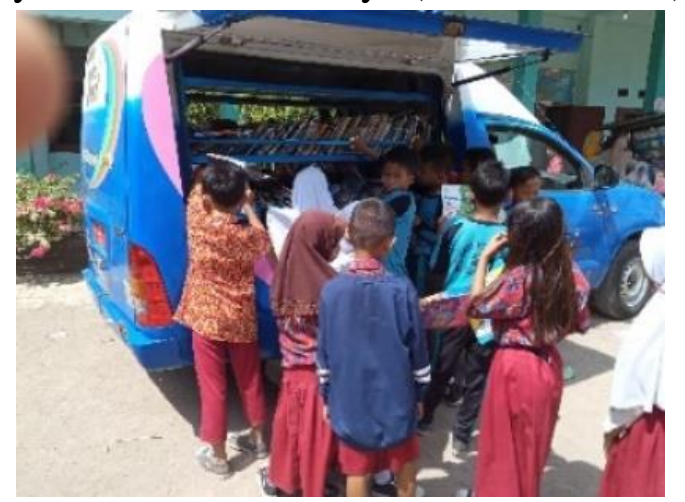

Gambar 2 Perpustakaan keliling 
Perpustakaan keliling merupakan kegiatan perpustakaan keliling ke daerah-daerah yang jauh sesuai dengan jadwal dan permintaan. Tujuannya ialah untuk memberikan dan mengenalkan masyarakat sekitar akan pentingnya kebiasaan membaca dan memberikan fasilitas untuk membaca. Kegiatan perpustakaan keliling ini akan dilakukan oleh tim petugas pustakawan yang telah dibentuk dan pihak terkait lainnya yang ingin ikut berpartisipasi dalam kegiatan perpustakaan keliling. Kegiatan perpustakaan keliling ini akan dilakukan secara berkelanjutan dan waktu yang ditentukan secara bersama dari pihak terkait

\section{Kesimpulan}

Standar nasional perpustakaan (SNP) menyatakan bahwasannya perpustakaan adalah sarana pembelajaran sepanjang hidup manusia. Dalam pemanfaatan sarana yang perlu adanya pelyanan yang professional dan sistem kerja yang baik dilingkungan perpustakaan. Berbagai strategi telah disusun guna menunjang tercapainya tujuan perpustakaan itu sendiri sehingga di buatlah perpustakaan keliling (pusling). Pusling yang dibuat oleh perpustakaan kota cirebon terdiri dari tim yang memiliki keahlian dalam rangka untuk menyampaikan pesan-pesan dan informasi serta mampu untuk menarik minat masyarakat agar mau membaca, pemilihan buku yang disesuaikan dengan tingkat pendidikan dan latar belakang masyarakat dan melakukan kerjasama dengan pemerintah daerah terkait, para pegiat literasi dari daerah lain, pemuda-pemudi (siswa/i dan mahasiswa/i) dan warga serta adanya biaya yang disediakan untuk biaya perawatan dan pemeliharaan. Dalam kegiatan pusling masyarakat di ajak untuk aktif membaca dan bercerita dengan metode storytelling dan adanya program literasi yang disesuaikan dengan lingkungan 


\section{BIBLIOGRAFI}

Aji, Seno Tri Bayu, \& Heriyanto, Heriyanto. (2013). Pengaruh Layanan Perpustakaan Keliling Terhadap Kemampuan Literasi Informasi "Wanita Tuna Susila (WTS)" di Lokalisasi Gambilangu Semarang. Jurnal Ilmu Perpustakaan, 2(4), 142-156.

Aulawi, Moch Basit. (2011). Optimalisasi layanan perpustakaan dalam meningkatkan minat baca siswa. Pustakaloka, 3(1), 117-127.

Ayuningtyas, Tika. (2015). Kualitas Layanan Di Perpustakaan Umum Kota Madiun (Studi Deskriptif Tentang Kualitas Layanan DenganMenggunakan LIBQUAL Di Perpustakaan Umum Kota Madiun). Universitas Airlangga.

Ekasari, Ratna, Pradana, M. Sungging, Adriansyah, Gusti, Prasnowo, M. Adhi, Rodli, A. Fathoni, \& Hidayat, Khoirul. (2017). Analisis Kualitas Pelayanan Puskesmas Dengan Metode Servqual. Jurnal Darussalam: Jurnal Pendidikan, Komunikasi Dan Pemikiran Hukum Islam, 9(1), 86-93.

Habsari, Zakia. (2017). Dongeng sebagai pembentuk karakter anak. BIBLIOTIKA: Jurnal Kajian Perpustakaan Dan Informasi, 1(1), 21-29.

Hs, Lasa. (2009). Meningkatkan Kualitas Layanan Perpustakaan Umum. Retrieved from http://repository.umy.ac.id/bitstream/handle/123456789/6370/Meningkatkan Kualitas Layanan Perpustakaan Umum.pdf?sequence=1\&isAllowed=y

Kadariyah, Nuzlianni. (2014). Pengelolaan Perpustakaan Keliling Di Perpustakaan Daerah Tangerang Selatan.

Nurdiana, Editya. (2018). Peningkatan Kualitas Sumber Daya Manusia Berbasis Masyarakat Untuk Mengatasi Masalah Pengangguran Di Wilayah Kabupaten Cirebon. Syntax Literate; Jurnal Ilmiah Indonesia, 3(2), 16-25.

Perpustakaan Nasional, R. I. (2011). Standar nasional perpustakaan. Jakarta: Perpustakaan Nasional RI.

Purboningsih, Dewi, Muluk, M. R. Khairul, \& Noor, Irwan. (2014). Peningkatan Kualitas Pelayanan Perpustakaan Umum Melalui Pendekatan Sistem Lunak (Soft System)(Studi Pada Perpustakaan Umum Kota Kediri). WACANA, Jurnal Sosial Dan Humaniora, 17(2), 105-116.

Sekaran, Uma. (2006). Metodologi penelitian untuk bisnis. Edisi.

Tedja, Rizki Fauzi. (2017). Efektivitas Teknik Bimbingan Literasi Dalam Meningkatkan Konsentrasi Belajar Siswa. Irsyad: Jurnal Bimbingan, Penyuluhan, Konseling, Dan Psikoterapi Islam, 5(3), 311-328.

Utomo, Sukarno Budi. (2013). Mendongeng dalam perspektif pendidikan. Agastya: Jurnal Sejarah Dan Pembelajarannya, 3(01). 
Taufik Ridwan, Muhammad Muqoyim dan Moh. Syauqi

Wibowo, Kukuh Ari. (2010). Layanan Ekstensi (Perpustakaan Keliling) Badan Perpustakaan Dan Arsip Daerah Provinsi Daerah Istimewa Yogyakarta. Skripsi, Program Diploma III Perpustakaan, Fakultas Ilmu Sosial Dan Politik, Universitas Sebelas Maret Surakarta.

Zen, Zulfikar. (2006). Manajemen Peprustakaan, Suatu Pendekatan Praktek. Jakarta: Sagung Seto. 